\title{
INFLUENCE OF UREA AND CHICKEN MANURE ON PRODUCING NEW PLANTS AND VEGETATIVE GROWTH OF STRAWBERRY (Fragaria x ananassa Duch) "DARSELECT" PLANTS
}

\author{
NAJI ISAM BARWARY \\ Dept. of Horticulture, College of Agricultural Engineering Science , University of Duhok, \\ Kurdistan Region - Iraq
}

(Received: September 6, 2021; Accepted for Publication: October 31, 2021)

\begin{abstract}
This study was performed during November 2020 to August 2021, in a private farm at Tishambik village, Kanimasi distract, Duhok, Kurdistan region / Iraq on strawberry plants Darselect cultivar to find out the effects of four levels of soil application urea $\left(0,1,1.5\right.$ and $2 \mathrm{~g}$ plant $\left.^{-1}\right)$ and three levels of chicken manure $(0$, 100 and $200 \mathrm{~g} \mathrm{plant}^{-1}$ ) on producing new plants and vegetative growth of strawberry plants. General obtained results showed that the incremental application of urea and chicken manure rates especially at $(2 \mathrm{~g}$ urea and $200 \mathrm{~g}$ chicken manure) led to significant increase most of the studied parameters. The interaction between urea with chicken manure at high rates resulted in the highest values of number of runners $\left(17\right.$ Plant $\left.^{-1}\right)$, length of runner $(125.67 \mathrm{~cm})$, number of seedlings $\left(5.33\right.$ Runner $\left.^{-1}\right)$, number of seedlings $\left(35.33\right.$ Plant $\left.^{-1}\right)$, dry weight of vegetative growth $\left(26.60 \mathrm{~g}\right.$. plant $\left.^{-1}\right)$, the total nitrogen in leaves $(3.79 \%)$, phosphorus $(0.83 \%)$ and potassium $(\mathbf{1 . 8 0} \%)$.
\end{abstract}

KEYWORD: strawberry, Urea, Chicken manure.

\section{INTRODUCTION}

$\mathbf{S}_{\mathrm{a}}^{\mathrm{t}}$ rawberry (Fragaria $\times$ ananassa Duch.) is perennial herbaceous plant and can grow in different climates, and adapted to temperate zones in the tropics and subtropics from high elevations of up to 3000 meters above sea level and have a nature highly heterozygous (Larson, 1994, Childers et al., 1995). Darselect strawberry is a high-yielding, widely adapted plasticulture or matted-row cultivar and demands a significant amount of nitrogen and adequate amounts of potassium and magnesium to improve the performance of the fruit during its growth (https://www.noursefarms.com , Product , Darselect). Strawberries are most important for the people in the world because of attractive colors, delicious and pleasant aroma (Sharma and Yamdagni, 2000). The people can be put to use Strawberry plants as a decorative plant in the home's yard can help in addition to enhancing the appearance of the yard, nutrition is the another reasons can also be used in family (Ginandjar et al., 2019). Strawberry plant grow fast and is extremely adapted to environmental factors such as light, temperature range, nutrients, the quality of the water for the growing and increase vegetative part the plants needs adequate absorption of macronutrients to help enhancement photosynthetic demand (Li et al., 2010). Strawberry plant can be grown in a variety of soil types, from heavy clay to light sand. The root system of plant is fibrous and the area confined this roots are $15-20 \mathrm{~cm}$ to the soil's top layer, and it thrives on light, porous soil that is nutrientdense. (Sharma and Singh, 1999; Sharma, 2002). Using of organic manures is beneficial to plants because they provide plants with essential nutrients and may help to improve soil fertility by improving the structure and hydro-physical qualities of the soil. (Grandy et al., 2002). Because of strawberry has shallow root system and a lot productivity is very responsible to nitrogen fertilizers, in related to plant size. Many researchers have reported on the stimulative effects of nitrogen fertilizer in strawberry cultivation on vegetative development. (Patrik and Martin, 1981; Moussa et al., 1993). (Deng and

naji.isam@uod.ac 
Woodward 1998) found that, when there is a lack of nitrogen, the overall biomass of strawberries suffers, in addition reducing the size of plant and fruits. (Kirschbaum et al. 2010) claim that, when $\mathrm{N}$ applications are submitted, the growth of plant exaggerated and are clearly evident, as the number of leaves grows, so does the sensitivity to diseases. (Abo Sedera et al., 2009) studied that the application of nitrogen fertilizer with compost or alone at $(2000 \mathrm{~kg} \mathrm{~N})$ had a significant impact on strawberry vegetative growth. Chicken manure improves structures of soil, nutrient maintenance,

The goal of this research was to determine the impact of urea and chicken manure on producing new seedlings and vegetative growth of strawberry plant.

\section{MATERIALS AND METHODS}

The experiment was carried out during the November 2020 to August 2021, in a private farm at Tishambik village, Kanimasi distract, Duhok, Kurdistan regions / Iraq. The local elevation is 900 $\mathrm{m}$ on sea level. The weather in the area is (cold to moderate), with rainy season from October to May, the soil is a silty loam, in order to study the impact of four doses of urea $(0,1,1.5$ and $2 \mathrm{~g}$ plant $\left.^{-1}\right)$ and three levels of chicken manure $(0,100$ and $200 \mathrm{~g} \mathrm{plant}^{-1}$ ) on growth of strawberry plant. The strawberry transplants was planted in $25 / 11 / 2020$ in the experimental farm, area of the experimental plot was $12 \mathrm{~m}^{2}$ contained three replications and each experimental unit have four plants, at the distance between each plant $40 \mathrm{~cm}$ and $50 \mathrm{~cm}$ between the rows. The test contained of twelve factorial treatments (four doses of urea, three levels of chicken manure). The used nitrogen source was urea, which was added manually three times during season growth, first 21 days from the date of planting, second the last week of March and third 1 May. Organic fertilizer source was chicken manure that contain high amount of mineral nutrients, uniformly and manually applied at the time of planting. After planting immediately irrigation was given in a light manner. and following irrigation is provided according to the crop's requirements.. From the beginning until the end of experiment drip irrigation was used. In this study, the experimental design was adopted the
Moisture-holding capability of soil, aeration and intrusion of water (Deksissa et al., 2008). It has a high ratio of $\mathrm{N}, \mathrm{P}$, and $\mathrm{K}$, as well as other vital nutrients. That provides phosphate and nitrogen to plants more easily than other organic manure sources (Garg and Bahla, 2008). (Mahadeen 2009) reported that the impact of chicken manure and $\mathrm{N}$, $\mathrm{P}$ and $\mathrm{K}$ chemical fertilizer $(20-20-20+$ micro elements) on strawberry fruit productivity and quality, as well as soil chemical qualities and significantly increased fresh and dry weights of shoots by application of organic fertilizer.

Randomize Complete Block Design used the data was analyzed and compared according to the Duncan's Multiple Range Tests at 5\% level (AlRawi and khalafalla, 2000) used SAS program. The following data will be recorded. Number of runners $\left(\right.$ Plant $\left.^{-1}\right)$, length of runner $(\mathrm{cm})$, Number of seedlings $\left(\right.$ Runner $\left.^{-1}\right)$, Number of seedlings (Plant ${ }^{-}$ $\left.{ }^{1}\right)$, dry weight of vegetative growth (g. plant ${ }^{-1}$ ) by used oven dried at $70{ }^{\circ} \mathrm{C}$ until the weight of plant was fixed (Al-Sahaf, 1989), the total nitrogen, phosphorus and potassium percentage dry samples of plant leaves digested in the acid solution were estimated as follow: The nitrogen was determined by using Microkjeldhal apparatus described by (A.O.A.C. 1975), phosphorous was estimated by using ammonium vanadium the reading of sample was recorded by Spectrophotometer apparatus $(410 \mathrm{~nm})$ (Olsen and Semmers, 1982). Potassium was determined by Flame photometer apparatus (Jenway PEP7, U.K.) reported by (page, et al., 1982 and A.O.A.C., 1995).

\section{RESULTS AND DISCUSSION \\ 1. Number of runners (Plant $\left.{ }^{-1}\right)$}

Data in table (1) shows the number of runners of strawberry plants which was significantly affected by urea using ( 1.5 and $2 \mathrm{~g}$ ) and chicken manure at level (200 g) as compared to the control treatment. In the case of a combination, a significant difference appears in term of number of runners especially at ( $2 \mathrm{~g}$ urea and $200 \mathrm{~g}$ chicken manure) compare with other interaction treatments. 
Table (1):- Influence of urea and chicken manure on number of runners (Plant $\left.{ }^{-1}\right)$ of strawberry "Darselect" plants

\begin{tabular}{|c|c|c|c|c|c|}
\hline \multirow{2}{*}{$\begin{array}{l}\text { Effect of chicken manure } \\
\text { g plant }^{-1}\end{array}$} & \multicolumn{4}{|c|}{ Effect of urea g plant ${ }^{-1}$} & \multirow{2}{*}{$\begin{array}{l}\text { Effect of chicken } \\
\text { manure } \\
\text { g plant }^{-1}\end{array}$} \\
\hline & 0 & 1 & 1.5 & 2 & \\
\hline 0 & $3.33 \mathrm{f}$ & 5.33 ef & $9.67 \mathrm{~cd}$ & $9.67 \mathrm{~cd}$ & $7.00 \mathrm{c}$ \\
\hline 100 & $12.00 \mathrm{~b}-\mathrm{d}$ & $8.67 \mathrm{de}$ & $12.00 \mathrm{~b}-\mathrm{d}$ & $13.33 \mathrm{bc}$ & $11.50 \mathrm{~b}$ \\
\hline 200 & $12.00 \mathrm{~b}-\mathrm{d}$ & $14.00 \mathrm{ab}$ & $15.00 \mathrm{ab}$ & $17.00 \mathrm{a}$ & $14.50 \mathrm{a}$ \\
\hline Effect of urea & $9.11 \mathrm{~b}$ & $9.33 \mathrm{~b}$ & $12.22 \mathrm{a}$ & $13.33 \mathrm{a}$ & \\
\hline
\end{tabular}

Means within a column, row and their interactions followed with the same letters are not significantly different from each other according to Duncan multiple ranges test at significant level of $5 \%$.

\section{2. length of runner $(\mathrm{cm})$}

Data present in table (2) reveal that using (2 $\mathrm{g}$ and $200 \mathrm{~g}$ ) level of urea and chicken manure respectively significantly increased length of each runner.
Concerning the interaction between soil application of urea and chicken manure, the best data were measured for length of each runner of 2 $\mathrm{g}$ of urea with $200 \mathrm{~g}$ of chicken manure which was $(125.67 \mathrm{~cm})$ compared with some of other interaction treatments.

Table (2):- Influence of urea and chicken manure on length of runner cm of strawberry "Darselect" plants

\begin{tabular}{cccccc}
\hline $\begin{array}{c}\text { Effect of chicken manure } \\
\text { g plant }{ }^{-1}\end{array}$ & \multicolumn{4}{c}{ Effect of urea g plant ${ }^{-1}$} & \multicolumn{2}{c}{\begin{tabular}{c} 
Effect of chicken manure $_{\text {g plant }^{-1}}$ \\
\cline { 2 - 5 }
\end{tabular}} & 0 & 1 & 1.5 & 2 & $51.33 \mathrm{c}$ \\
\hline 0 & $34.33 \mathrm{f}$ & $53.67 \mathrm{ef}$ & $54.67 \mathrm{ef}$ & $62.67 \mathrm{~d}-\mathrm{f}$ & $74.83 \mathrm{~b}$ \\
\hline 100 & $50.00 \mathrm{ef}$ & $73.33 \mathrm{c}-\mathrm{e}$ & $76.67 \mathrm{c}-\mathrm{e}$ & $99.33 \mathrm{a}-\mathrm{c}$ & $104.17 \mathrm{a}$ \\
\hline 200 & $88.67 \mathrm{~b}-\mathrm{d}$ & $92.00 \mathrm{bc}$ & $110.33 \mathrm{ab}$ & $125.67 \mathrm{a}$ & \\
\hline Effect of urea & $57.67 \mathrm{c}$ & $73.00 \mathrm{~b}$ & $80.56 \mathrm{~b}$ & $95.89 \mathrm{a}$ & \\
\hline
\end{tabular}

Means within a column, row and their interactions followed with the same letters are not significantly different from each other according to Duncan multiple ranges test at significant level of 5\%.

\section{Number of seedlings $\left(\right.$ Runner $\left.^{-1}\right)$}

The data in table (3) clarified that significantly affected on number of seedlings per runner were obtained with treatments that received $(2 \mathrm{~g}$ and $200 \mathrm{~g}$ ) of urea and chicken manure respectively compared to control. The interaction between application of urea at $2 \mathrm{~g}$ and chicken manure at $200 \mathrm{~g}$ had significant effect on number of seedlings per runner that was (5.33 seedlings. runner ${ }^{-1}$ )as compared with most of other interaction treatments.

Table (3):- Influence of urea and chicken manure on number of seedlings $\left(\right.$ Runner $\left.^{-1}\right)$ of strawberry "Darselect" plants

\begin{tabular}{|c|c|c|c|c|c|}
\hline \multirow{2}{*}{$\begin{array}{c}\text { Effect of chicken manure } \\
\text { g plant }^{-1}\end{array}$} & \multicolumn{4}{|c|}{ Effect of urea g plant ${ }^{-1}$} & \multirow{2}{*}{$\begin{array}{l}\text { Effect of chicken manure } \\
\text { g plant }^{-1}\end{array}$} \\
\hline & 0 & 1 & 1.5 & 2 & \\
\hline 0 & $2.00 \mathrm{e}$ & $3.33 c-e$ & $3.33 c-e$ & $3.00 \mathrm{de}$ & $2.92 \mathrm{c}$ \\
\hline 100 & $4.00 \mathrm{a}-\mathrm{d}$ & $3.67 b-d$ & $3.67 b-d$ & $3.67 b-d$ & $3.75 \mathrm{~b}$ \\
\hline 200 & $3.33 \mathrm{c}-\mathrm{e}$ & $4.67 \mathrm{a}-\mathrm{c}$ & $5.00 \mathrm{ab}$ & $5.33 \mathrm{a}$ & $4.58 \mathrm{a}$ \\
\hline Effect of urea & $3.11 \mathrm{~b}$ & $3.89 a b$ & $4.00 \mathrm{a}$ & $4.00 \mathrm{a}$ & \\
\hline
\end{tabular}

Means within a column, row and their interactions followed with the same letters are not significantly different from each other according to Duncan multiple ranges test at significant level of 5\%.

\section{Number of seedlings $\left(\right.$ Plant $\left.^{-1}\right)$}

Number of seedlings per plant was increased by (1.5 and $2 \mathrm{~g}$ ) of urea compared to control as shown in table (4). Also used of chicken manure at $200 \mathrm{~g}$ 
had significant increased number of seedlings per plant which was $\left(29.83\right.$. seedlings plant $\left.{ }^{-1}\right)$ compared to control (21.83 seedlings plant $\left.{ }^{-1}\right)$. The interaction between application urea at $2 \mathrm{~g}$ and chicken manure at $200 \mathrm{~g}$ obtained the best record that was (35.33 seedlings plant $\left.{ }^{-1}\right)$ compared to some other interaction treatments.

Table (4):- Influence of urea and chicken manure on number of seedlings $\left(\mathrm{Plant}^{-1}\right)$ of strawberry "Darselect" plants

\begin{tabular}{|c|c|c|c|c|c|}
\hline \multirow{2}{*}{$\begin{array}{l}\text { Effect of chicken manure } \\
\text { g plant }{ }^{-1}\end{array}$} & \multicolumn{4}{|c|}{ Effect of urea g plant ${ }^{-1}$} & \multirow{2}{*}{$\begin{array}{l}\text { Effect of chicken manure } \\
\text { g plant }^{-1}\end{array}$} \\
\hline & 0 & 1 & 1.5 & 2 & \\
\hline 0 & $8.00 \mathrm{~d}$ & $17.33 \mathrm{~cd}$ & $33.00 \mathrm{ab}$ & $29.00 \mathrm{a}-\mathrm{c}$ & $21.83 b$ \\
\hline 100 & $28.67 \mathrm{a}-\mathrm{c}$ & $22.33 b c$ & $20.00 \mathrm{c}$ & $23.33 b c$ & $23.58 \mathrm{~b}$ \\
\hline 200 & $26.33 \mathrm{a}-\mathrm{c}$ & $22.67 \mathrm{bc}$ & $35.00 \mathrm{a}$ & $35.33 \mathrm{a}$ & $29.83 \mathrm{a}$ \\
\hline Effect of urea & $21.00 \mathrm{~b}$ & $20.78 b$ & $29.33 \mathrm{a}$ & $29.22 \mathrm{a}$ & \\
\hline
\end{tabular}

Means within a column, row and their interactions followed with the same letters are not significantly different from each other according to Duncan multiple ranges test at significant level of $5 \%$.

\section{Dry weight of vegetative growth (g. plant $\left.{ }^{-1}\right)$}

Dry weight of vegetative growth of strawberry plant was significantly affected by urea addition at (1.5 and $2 \mathrm{~g}$ ) and chicken manure at $200 \mathrm{~g}$ in comparison to the control treatment clear in (table 5). Interaction also showed significant differences especially at $(2 \mathrm{~g}$ urea and $200 \mathrm{~g}$ chicken manure) in compared to all other interaction treatments.

Table (5):- Influence of urea and chicken manure on dry weight of vegetative growth (g. plant ${ }^{-1}$ ) of strawberry "Darselect" plants

\begin{tabular}{cccccc}
\hline $\begin{array}{c}\text { Effect of chicken manure } \\
\text { g plant }\end{array}$ & \multicolumn{3}{l}{ Effect of urea g plant } \\
\cline { 2 - 5 } & 0 & 1 & 1.5 & 2 & $\begin{array}{c}\text { Effect of chicken manure } \\
\text { g plant }^{-1}\end{array}$ \\
\hline 0 & $13.37 \mathrm{e}$ & $14.69 \mathrm{e}$ & $16.86 \mathrm{de}$ & $16.46 \mathrm{de}$ & $15.35 \mathrm{c}$ \\
\hline 100 & $18.86 \mathrm{~cd}$ & $14.88 \mathrm{e}$ & $21.69 \mathrm{bc}$ & $20.08 \mathrm{~cd}$ & $18.88 \mathrm{~b}$ \\
\hline 200 & $19.24 \mathrm{~cd}$ & $22.20 \mathrm{bc}$ & $24.56 \mathrm{ab}$ & $26.60 \mathrm{a}$ & $23.15 \mathrm{a}$ \\
\hline Effect of urea & $17.16 \mathrm{~b}$ & $17.26 \mathrm{~b}$ & $21.04 \mathrm{a}$ & $21.05 \mathrm{a}$ & \\
\hline
\end{tabular}

Means within a column, row and their interactions followed with the same letters are not significantly different from each other according to Duncan multiple ranges test at significant level of $5 \%$.

\section{Nitrogen percentage in leaves}

Results in table (6) obviously revealed that soil application of urea at $2 \mathrm{~g}$ gave highest value of nitrogen percentage in leaf of strawberry plant (3.21\%). Application of chicken manure at $200 \mathrm{~g}$ level significantly increased nitrogen percentage in leaves of strawberry compare to the control. For the interaction between urea and chicken manure, the results indicated that soil application of $2 \mathrm{~g}$ urea + $200 \mathrm{~g}$ chicken manure had the maximum significant nitrogen percentage $(3.79 \%)$. But minimum nitrogen percentage $(2.16 \%)$ was recorded of interaction between $0 \mathrm{~g}$ urea and $0 \mathrm{~g}$ chicken manure. 
Table (6):- Influence of urea and chicken manure on nitrogen percentage in leaves of strawberry "Darselect" plants

\begin{tabular}{|c|c|c|c|c|c|}
\hline \multirow{2}{*}{$\begin{array}{l}\text { Effect of chicken manure } \\
\text { g plant }^{-1}\end{array}$} & \multicolumn{4}{|c|}{ Effect of urea g plant ${ }^{-1}$} & \multirow{2}{*}{$\begin{array}{l}\text { Effect of chicken manure } \\
\text { g plant }^{-1}\end{array}$} \\
\hline & 0 & 1 & 1.5 & 2 & \\
\hline 0 & $2.16 \mathrm{c}$ & $2.33 \mathrm{bc}$ & $3.04 \mathrm{a}-\mathrm{c}$ & $3.00 \mathrm{a}-\mathrm{c}$ & $2.63 \mathrm{~b}$ \\
\hline 100 & $3.33 \mathrm{a}$ & $3.10 \mathrm{a}-\mathrm{c}$ & $2.83 \mathrm{a}-\mathrm{c}$ & $2.84 \mathrm{a}-\mathrm{c}$ & $3.03 a b$ \\
\hline 200 & $2.97 \mathrm{a}-\mathrm{c}$ & $2.89 \mathrm{a}-\mathrm{c}$ & $3.32 \mathrm{ab}$ & $3.79 \mathrm{a}$ & $3.24 \mathrm{a}$ \\
\hline Effect of urea & $2.82 \mathrm{a}$ & $2.77 \mathrm{a}$ & $3.07 \mathrm{a}$ & $3.21 \mathrm{a}$ & \\
\hline
\end{tabular}

Means within a column, row and their interactions followed with the same letters are not significantly different from each other according to Duncan multiple ranges test at significant level of $5 \%$.

\section{Phosphorus percentage in leaves:}

Table (7) cleared that soil application of urea to strawberry plant $1.5 \mathrm{~g}$ gave highest value $(0.65 \%)$ of phosphorus percentage in leaf of Darselect cultivar. Application of chicken manure showed $(200 \mathrm{~g})$ level of chicken manure significantly increased phosphorus percentage in leaf compared to control. The same table shows that application of ( $2 \mathrm{~g}$ urea with $200 \mathrm{~g}$ chicken manure) significantly affected on phosphorus percentage the highest value was $(0.83 \%)$ compared to the lowest phosphorus percentage value was $(0.22 \%)$ recorded in control.

Table (7): -Influence of urea and chicken manure on phosphorus percentage in leaves of strawberry "Darselect" plants

\begin{tabular}{|c|c|c|c|c|c|}
\hline \multirow{2}{*}{$\begin{array}{l}\text { Effect of chicken manure } \\
\text { g plant }^{-1}\end{array}$} & \multicolumn{4}{|c|}{ Effect of urea g plant ${ }^{-1}$} & \multirow{2}{*}{$\begin{array}{l}\text { Effect of chicken manure } \\
\text { g plant }^{-1}\end{array}$} \\
\hline & 0 & 1 & 1.5 & 2 & \\
\hline 0 & $0.22 \mathrm{e}$ & $0.40 \mathrm{c}-\mathrm{e}$ & $0.72 \mathrm{ab}$ & $0.33 \mathrm{de}$ & $0.42 \mathrm{~b}$ \\
\hline 100 & $0.67 \mathrm{a}-\mathrm{c}$ & $0.43 \mathrm{~b}-\mathrm{e}$ & $0.56 a-d$ & 0.44 b-e & $0.53 \mathrm{~b}$ \\
\hline 200 & $0.64 \mathrm{a}-\mathrm{c}$ & $0.69 a-c$ & $0.66 \mathrm{a}-\mathrm{c}$ & $0.83 \mathrm{a}$ & $0.70 \mathrm{a}$ \\
\hline Effect of urea & $0.51 \mathrm{a}$ & $0.51 \mathrm{a}$ & $0.65 \mathrm{a}$ & $0.53 \mathrm{a}$ & \\
\hline
\end{tabular}

Means within a column, row and their interactions followed with the same letters are not significantly different from each other according to Duncan multiple ranges test at significant level of 5\%.

\section{Potassium percentage in leaves:}

Table (8) clearly shows that application of both urea and chicken manure significantly affected on potassium percentage in leaf of strawberry plants. Which records the maximum value $(1.47 \%)$ at $(2$ g) dose urea and $(1.62 \%)$ at $(200 \mathrm{~g})$ level chicken manure compared to the control. Data showed that $2 \mathrm{~g}$ urea $+200 \mathrm{~g}$ chicken manure gave significantly the maximum potassium percentage in leaf compared to minimum value obtained at control ( $0 \mathrm{~g}$ urea $+0 \mathrm{~g}$ chicken manure) .

Table (8):- Influence of urea and chicken manure on potassium percentage in leaves of strawberry "Darselect" plants

\begin{tabular}{|c|c|c|c|c|c|}
\hline \multirow{2}{*}{$\begin{array}{l}\text { Effect of chicken manure } \\
\text { g plant }^{-1}\end{array}$} & \multicolumn{4}{|c|}{ Effect of urea g plant ${ }^{-1}$} & \multirow{2}{*}{$\begin{array}{c}\text { Effect of chicken } \\
\text { manure } \\
\text { g plant }^{-1}\end{array}$} \\
\hline & 0 & 1 & 1.5 & 2 & \\
\hline 0 & $0.32 \mathrm{~g}$ & $0.50 \mathrm{fg}$ & $0.74 \mathrm{e}-\mathrm{g}$ & $1.10 c-e$ & $0.66 \mathrm{c}$ \\
\hline 100 & $1.00 \mathrm{~d}-\mathrm{e}$ & $1.26 \mathrm{a}-\mathrm{e}$ & $1.16 \mathrm{~b}-\mathrm{e}$ & $1.51 \mathrm{a}-\mathrm{d}$ & $1.23 \mathrm{~b}$ \\
\hline 200 & $1.47 \mathrm{a}-\mathrm{d}$ & $1.56 \mathrm{a}-\mathrm{c}$ & $1.66 \mathrm{ab}$ & $1.80 \mathrm{a}$ & $1.62 \mathrm{a}$ \\
\hline Effect of urea & $0.93 \mathrm{~b}$ & $1.11 \mathrm{~b}$ & $1.19 \mathrm{ab}$ & $1.47 \mathrm{a}$ & \\
\hline
\end{tabular}

Means within a column, row and their interactions followed with the same letters are not significantly different from each other according to Duncan multiple ranges test at significant level of 5\%. 
It's obvious from tables (1-8) that soil application of urea and chicken manure had significant effect on increasing strawberry seedlings parameters, vegetative growth, nitrogen, phosphorus, potassium percentage in leaves undertaken in this experiment of strawberry plant cv. Darselect, the positive effect of urea might be attributed to an increase in nitrogen absorption and its crucial function in chlorophyll synthesis and as a result, the photosynthesis and carbon dioxide assimilation processes (Jasso-chaverria et al., 2005) leading to enhanced growth. Such desirable effects of application of nitrogen on vegetative growth parameters could be attributed to the nitrogen's ability to promote metabolic activity in order to aid in the production of more tissues and organs (Yagodin 1984). The effect of chicken manure on strawberry vegetative development has been observed could be attributed to the enhanced nutrient availability over a longer period of time throughout the planting season; this encourages plant growth to progress (Mohamed and Gabr, 2002). The number of runner of each plant can be increased might the organic matters contain of plant-growth regulating substances and improvement of soil biological function (Cristina and Jorge, 2011) through the application of chicken manure to soil. Organic amendments as well as helpful in cell division and cell elongation in meristimatic region of plant, this was because of the production of plant growth substances IAA and GA (Gopalreddy, 1997; Willrich et al., 1974; Sims, 1987).

Organic manures enhance strawberry plant vegetative development characteristics by enhancing soil aeration and promoting soil enzyme activity (Bhattacharyya et al. 2003). The maximum number of runners in chicken manures treated plants could be due to plant nutrients are readily available, assisting strawberry plants in their vegetative growth, (Younas and Ali 2012).

\section{CONCLUSION}

Based on the findings of the current investigation into the influence of urea and chicken manures on producing new plants and vegetative growth of strawberry can be drawn this conclusion. Additions of urea at $2 \mathrm{~g}$ and chicken manure at $200 \mathrm{~g}$ have a significant effect and increasing on number of runners, length of runner, number of seedlings $\left(\right.$ Runner $\left.^{-1}\right)$, number of seedlings $\left(\right.$ Plant $\left.^{-1}\right)$, dry weight of vegetative growth, total nitrogen, phosphorus and potassium percentage in leaves. The interaction of urea with chicken manures in the high level the most effective treatment resulted in an increase in vegetative growth indices. We can conclude from this test the possibility of replacing the poultry or sheep manure and use fertilizer contain high amount of nitrogen or planting leguminous crops before planting strawberry in order to improve the parameters of vegetative growth.

\section{REFERENCE}

A. O. A. C. (1975). Official Methods of Analyses Association of Official Analytical Chemists. Washington D. C., $12^{\text {th }}$ Ed.

Abo Sedera, F.A.; Shafshak, S.N.; Eid, M.S. and Mohamed, M.H.M. (2009). Improving productivity and quality of strawberry via organic fertilization and application of some natural growth stimulants.3rd IRT international tourisum territories and development in the Mediterranean area, Helwan Univ., Egypt, From 24 th to 27 th October.

Al-Rawi, K. M. and Khalafalla. A. (2000). Analysis of Experimental Agriculture Disgen. Dar Al-Kutub for Printing and Publishing. Mosul Univ. (In Arabic).

Al-Sahaf, F. H. (1989). Agriculture systems without using soil. Ministry of Higher Education and Scientist Res. Baghdad Univ. Iraq.

Bhattacharyya P, Chakrabarti K, Chakraborty A. (2003). Effect of MSW compost on microbiological and biochemical soil quality indicators Compos Science and Utilization; 11(3):220-227.

Childers NF, Morris JR, Sibbett GS. (1995). Modern Fruit Science Horticulture Publication Grains YiLLE, Florida, U.S.A,.

Cristina, L. and Jorge, D. (2011). The use of vermicompost in sustainable agriculture: Impact on plant growth and soil fertility. In: Soil Nutrients, Nova Science Publishers, Chapter 10, pp. 2-16.

Darselect Strawberry Plant - Nourse Farms https://www.noursefarms.com > Product > Darselect.

Deksissa, T., Short, I. and Allen, J. (2008). Effect of soil amendment with compost on growth and water use efficiency of Amaranth. In: Proceedings of the UCOWR/NIWR annual conference: International water resources: challenges for the 21 st century and

naji.isam@uod.ac 
water resources education, July 22-24, 2008, Durham, NC.

Deng, X.; Woodward, F. I. (1998). The growth and yield responses of Fragaria ananassa to elevated $\mathrm{CO}_{2}$ and N Supply. Annals of Botany, v.81, p.67-

71,. http://dx.doi.org/10.1006/anbo.1997.0535.

Garg, S. and Bahla, G.S. (2008). Phosphorus availability to maize as influenced by organic manures and fertilizer $\mathrm{P}$ associated Phosphatase activity in soils. Bioresource Technology, 99(13): 5773-5777.

Ginandjar, S; Frasetya, B; Nugraha, W; and Subandi, M. (2019). The Effect of Liquid Organic Fertilizer of Vegetable Waste and Planting Media on Growth and Yield of Strawberry (Fragariaspp.) Earlibrite Cultivar. IOP Conf. Series: Earth and Environmental Science 334 - 012033

Gopalreddy, B. (1997). Soil health under integrated nutrient management in maize soybean cropping system. A PhD Thesis, Acharya N.G. Ranga Agricultural University, Rajendranagar, Hyderabad, Andhra Pradesh, India. pp. 125-173.

Grandy, A.S., Porter, G.A. and Erich, M.S. (2002).Organic amendment and rotation crop effects on the recovery of soil organic matter and aggregation in potato cropping systems. Soil Science Society of America Journal, 66:1311-1319.

Jasso-Chaverria, C; Hochmuth. G.J; Hochmuth. R.C; Sargent. S.A, (2005). Fruit yield, size, and colour responses of two Greenhouse cucumber types to nitrogen fertilization in perlite soilless culture. Horticulture Technology. 15:565.

Kirschbaum, D. S.; Larson, K. D.; Weinbaum, S. A.; DeJong, T. M. (2010).Late-season nitrogen applications in high-latitude strawberry nurseries improve transplant production pattern in warm regions. African Journal of Biotechnology, v.9, p.1001-1007,

Larson KD. Schaffer, B and Anderson, P.C. (1994). Strawberry (In): Handbook of environmental physiology of fruit crops 1: Temperate crops (Eds). CRC, Press. Inc, 271-297.

Li, H.; Huang, R.; Li, T.; Hu, K. (2010). Ability of nitrogen and phosphorus assimilation of seven strawberry cultivars in a northern Atlantic coastal soil. In: World Congress of Soil Science, Soil
Solutions for a Changing World, 19, , Brisbane. Anais...Brisbane: EPSO. CD-Rom.

Mahadeen, AY. (2009). Influence of organic and chemical fertilization on fruit yield and quality of plastic-house grown strawberry. Journal of Horticulture Sciences.; 5:445-449.

Moussa, A.G; El-Shal, M.A. and Ghoneim, I.M.. (1993). Morphological responses of strawberry to high supplying of $\mathrm{K}$ and $\mathrm{N}$ fertilizers. Menofiya $\mathrm{J}$. Agric. Res. 18 (4): 2633-2647.

Olsen, S. R. and Semmers. L. E. (1982). Chemical and microbiological properties, $2^{\text {nd }}$ ed, Amer. Soc. Agro. Madison, WI, USA. Phpsphorus: 403-430 In: A. L. Page, Methods of soil analysis, Agro. 9 (2).

Page, A. L.; Miller, R. H. and Keeney, O. R. (1982). Methods of Soil Analysis. Part. Amer. Soc. Agro. Inc. Publisher, Madison, Wisconsin, U.S.A.

Patrick, J.B and Martin, L.W. (1981). Vegetative and reproductive growth responses of three strawberry cultivars to nitrogen. J. Amer. Soc. Hort. Sci. 106 (3): 266-272.

SAS Institute.(2015).Base SAS 9.4 procedures guide. SAS Institute. USA.

Sharma RM, Yamdagni R. Modern strawberry cultivation. Ludhiana, India, Kalyani Pub. 2000; 37(1):163-165.

Sharma, RM, Yamdagni, R. (2000). Modern strawberry cultivation. Ludhiana, India, Kalyani Pub.; 37(1):163-165.

Sharma RR, Singh SK. Strawberry Cultivation a highly remunerative farming enterprise. Agro. India. 1999; 3:20-22.

Sims, J.T. (1987). Agronomic evaluation of poultry manure as nitrogen source for conventional and no tillage corn. Agronomy Journal, 79:563-582.

Willrich, T.; Jurmer, D.O. and Volk, V.V. (1974). Manure application guidelines for pacific northwest, ASAE paper No. 74-4601. American Society of Agricultural Engineers, St. Joseph, MI.

Yagodin, B.A. (1984). Agricultural Chemistry 1st ed. Mir Publishers.Moscow.

Younas M, Ali R. (2012). Influence of organic manuring on growth and yield of strawberry cv. Chandler. Asian Journal of Agriculture.; 3:169-171.

naji.isam@uod.ac 
" Darselect " تأثيراليوريا وسماد مخلفات الدجاج على انتاج شتلات جديدة و النمو الخضرى لشتلات الشليك

الخلاصة

أجريت هذه التجربه خلال الموسم الزراعي تشرين الثانى 2020 الى اب 2021 في مزرعة خاصة بقرية تيشمبيك، بروارى بالا، اقليم كردستان / العراق. على نبات الشليك صنف Darselect لدراسة تاثير أربع جرعات من اليوريا (صفر و 1 و 1,5 و غم. نبات-1)، وثلاثة مستويات من مخلفات الدجاج (صفر و100 و 200 غم. نبات-1) على انتاج شتلات جديدة و النمو الخضرى لشتلات الشليك. النتائج أظهرت ان زئه زيادة اضافة اليوريا و مخلفات دجاج خاصة عند (2 غم يوريا و 200 غم مخلفات دجاج) على التوالي ، ادت الى تحسين معظم الصفات المدروسة.

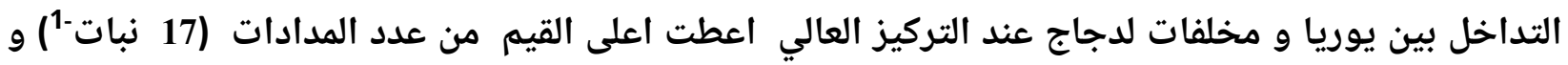

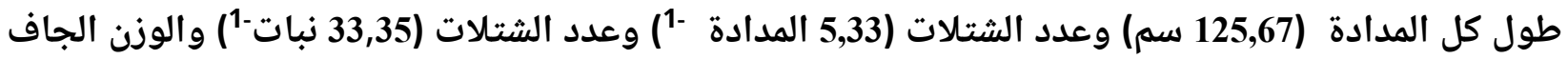
للجزء الخضري(26,60 غم. نبات-1) و محتوى النيتروجين في الأوراق (\%3,79\%) والفسفور (0,83\%) و البوتاسيوم

كلمات مفتاحيه: شليك , يوريا , سماد دجاج

كارتيّكرنا خوراكيّ يوريا وة زبلّ مريشكيّ ل سةر ضيّكرنا شتليّن نى وة ساخلة تيّن شينكاتيى ذ رووةكى شليّك

" Darselect " متليّن جوريّي ل

ئةظ ظةكولينة هاتة ئة نجامدان دوةرزىَ ضاندنى تشرينا دووى 2020 تا تةباخا 2021 د ناف زةفيةكا تايبةت ل طوندى تيشة مبيكيّ، بةروارى بالا، دهوك، هةريَما كوردستانا عيراقَى. ل سةر رووةكى شليّك جوريّ

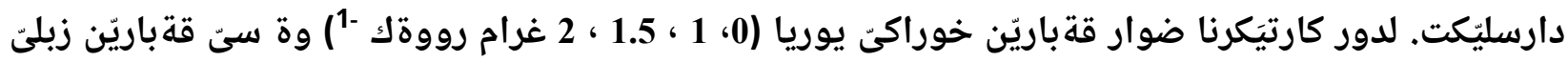

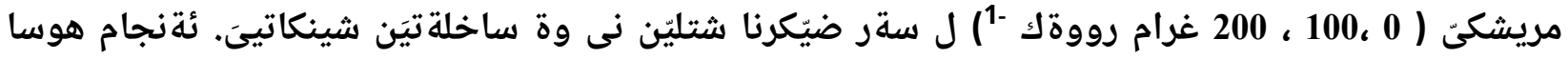
دياركرن كو زيّدة كرنا خوراكيّ يوريا وة زبلىّ مريشكى ب تابةت د قدة باريّ ( 2 غرام وة 200 غرام ) ل ديفك بو ئة طةريّ زيّدة كرنا ثترييا ساخلة تيّن هاتينة وةروطرتن. تيَكةل كرنا كارتيَكةرا دناظبةرا خوراكيّ يوريا وة زبلى مريشكى د قةباريّ زيّدة دا بلندترين ريَّة ذة ذ ذمارا كشوكا ( 17 رووة كَ -1) ، دريّذاهييا هةر كشوكةكيّ ( 125.67 سم) ، ذمارا شتلا( 5.33 كشوك -1) ، ذمارا شتلا(35.33 رووة ك -1) ، كيَشةيا هشك يا رووة دكى (26.60 غرام

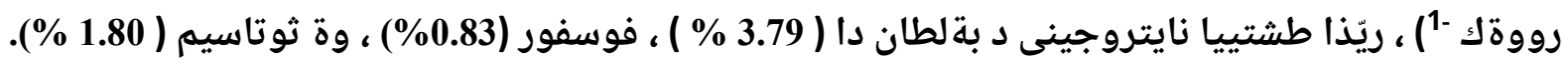

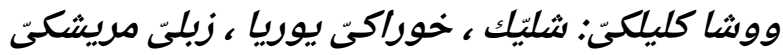

